\title{
Influence of a mixed and a vegetarian diet on urinary magnesium excretion and concentration
}

\author{
BY ROSWITHA SIENER AND ALBRECHT HESSE \\ Experimentelle Urologie, Klinik und Poliklinik für Urologie der Universität Bonn, \\ Sigmund-Freud-Str. 25, D-53105 Bonn, Germany
}

(Received 5 May 1993 - Revised 1 July 1994 - Accepted 24 August 1994)

\begin{abstract}
Urinary $\mathrm{Mg}$ is suggested to be an effective inhibitor of the formation and growth of calcium oxalate stones. In order to examine the influence of variations in dietary $\mathrm{Mg}$ on urinary $\mathrm{Mg}$ excretion, ten healthy male subjects were kept on two different standard diets for $5 \mathrm{~d}$ each. In the course of the test period, $24 \mathrm{~h}$ urine samples were collected. Diets 1 and 2 were calculated according to the dietary recommendations of the German Society of Nutrition (Deutsche Gesellschaft für Ernährung, 1986). Diet 1 was established as a model of a balanced mixed diet, whereas diet 2 represented an ovo-lacto-vegetarian meal plan. Diets 1 and 2 were isoenergetic with equal amounts of the main nutrients, estimated from food tables, and a constant fluid intake. In contrast to the content of $\mathrm{Mg}(336 \mathrm{mg})$ and dietary fibre $(28 \mathrm{~g})$ of diet 1 , diet 2 was rich in $\mathrm{Mg}(553 \mathrm{mg})$ and dietary fibre $(52 \mathrm{~g})$. On the ingestion of diet 1 , renal $\mathrm{Mg}$ excretion was 5.09 (SEM 0.35) mmol on the control day and increased slightly but not significantly to 5.40 (SEM 0.52) $\mathrm{mmol}$ on the corresponding day on diet 2. Urinary Mg excretion as a percentage of estimated dietary intake was about double on the balanced mixed diet (37\%) than on the Mg-rich vegetarian diet $(24 \%)$. As both diets contained equal amounts of most nutrients, these results indicate a lower excretion rate of $\mathrm{Mg}$ from the vegetarian diet than from the mixed diet. This would appear to be primarily due to the higher $\mathrm{Mg}$ and fibre contents and to the lower $\mathrm{Mg}$ utilization, that are important factors in decreasing $\mathrm{Mg}$ absorption and consequently urinary excretion rate.
\end{abstract}

Mixed diet: Vegetarian diet: Magnesium: Calcium: Lithiasis

The importance of urinary $\mathrm{Mg}$ excretion as an inhibitory factor of the formation and growth of calcium oxalate urinary stones has been indicated by various experimental investigations. In vitro studies either with artificial or human whole urine revealed a marked reduction of both the nucleation and growth rates of calcium oxalate crystals at various concentrations (Hallson et al. 1982; Achilles \& Ulshöfer, 1985; Li et al. 1985; Kohri et al. 1988).

The mechanism of action of $\mathrm{Mg}$ is most likely to increase the solubility of calcium oxalate, presumably by forming more soluble complexes (ion pairs) with oxalate ions that are then not available for precipitation by Ca (Desmars \& Tawashi, 1973).

These findings indicate the importance of a sufficiently high $24 \mathrm{~h}$ excretion and concentration of $\mathrm{Mg}$ as an effective metaphylactic measure in preventing recurrent stone disease. Related clinical investigations of Mg therapy have been conducted on recurrent stone formers as on healthy subjects but with little success. Indeed, the oral administration of $\mathrm{Mg}$ supplements resulted in a significant increase in urinary excretion, but this benefit was counteracted by the associated increase in urinary Ca excretion (Heaton \& Parsons, 1961; Briscoe \& Ragan, 1966; Fetner et al. 1978; Tiselius et al. 1980). On the other hand, the effect of various dietary $\mathbf{M g}$ supplies on urinary excretion of $\mathbf{M g}$ is not well documented. 
Table 1. Study protocol

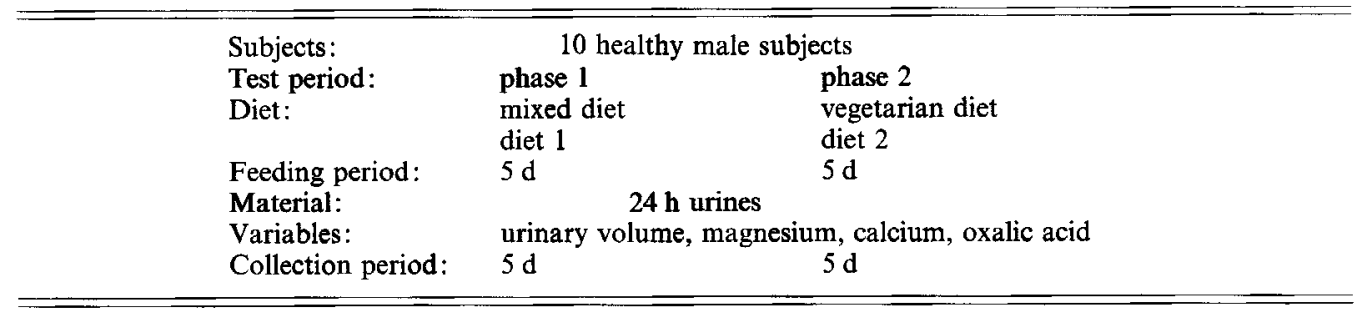

In order to determine a recommendable diet for the prevention of recurrent calcium oxalate stone disease we studied the influence of a balanced mixed diet, that ensures an adequate $\mathrm{Mg}$ intake (approximately $350 \mathrm{mg} / \mathrm{d}$ ), and a $\mathrm{Mg}$-rich vegetarian diet (approximately $550 \mathrm{mg} / \mathrm{d}$ ) on $24 \mathrm{~h}$ excretion and concentration of $\mathrm{Mg}$ in healthy men.

\section{SUBJECTS AND METHODS}

The present study was performed on ten healthy male subjects with a mean age of 28 years (range 21-32 years). The individuals had no history of renal calculus or other renal disorders. Before starting the test phases the subjects were fed on an adaptation diet, providing about $350 \mathrm{mg} \mathrm{Mg} / \mathrm{d}$ for $5 \mathrm{~d}$. The test series was divided into two consecutive phases of $5 \mathrm{~d}$ each. In the course of the test phases 1 and 2 the subjects received two different standard diets, diet 1 and diet 2. The protocol is summarized in Table 1.

Whereas diet 1 was established as a model of a balanced mixed diet (Table 2), diet 2 represented an ovo-lacto-vegetarian meal plan, since vegetables, especially green leafy vegetables, fruits and cereals, are rich in $\mathrm{Mg}$ (Table 3). Diets 1 and 2 were calculated according to the dietary recommendations of the German Society of Nutrition (Deutsche Gesellschaft für Ernährung, 1986). Nutrient contents of the diets were estimated by use of the computer program PRODI III plus, which includes fifty different nutrients mainly according to the Food Composition and Nutrition Tables, 1986/87 of Souci et al. (1986). The oxalic acid content of the diets was estimated from the data of Hodgkinson (1977).

Both diets were isoenergetic with equal amounts of the main nutrients and a constant fluid intake. The main components of the mixed diet 1 and the vegetarian diet 2 are specified in Table 4 . In contrast to the normal contents of $\mathrm{Mg}(336 \mathrm{mg} / \mathrm{d})$ and dietary fibre $(28 \mathrm{~g} / \mathrm{d})$ of diet 1 , diet 2 was rich in $\mathrm{Mg}(553 \mathrm{mg} / \mathrm{d})$ and dietary fibre $(52 \mathrm{~g} / \mathrm{d})$.

With diet 1 , dietary fibre and $\mathrm{Mg}$ were supplied equally by cereals and fruits, whereas the intake of these nutritional components from vegetables was comparatively low. In comparison, the fibre and $\mathrm{Mg}$ intakes from vegetables and fruits in diet 2 were three times as much as with diet 1 , whereas the intake of these dietary components from cereals remained unchanged compared with diet 1 (Table 5).

In the course of the test period, $24 \mathrm{~h}$ urine samples were collected each day. $\mathrm{Mg}$ concentration was determined by atomic absorption spectrophotometry and $24 \mathrm{~h}$ excretion of $\mathrm{Mg}$ was calculated from the concentration data and the urinary volumes. Other variables, such as urinary $\mathrm{Ca}$ (atomic absorption spectrophotometry), oxalic acid (ion chromatography) and creatinine (Jaffé-reaction), were also measured in $24 \mathrm{~h}$ urine samples.

The Wilcoxon signed-rank test (Sachs, 1984) was used to find significant differences 
Table 2. Menu for diet 1 (mixed diet)

\begin{tabular}{|c|c|}
\hline Breakfast: & $\begin{array}{l}100 \mathrm{~g} \text { bread rolls } \\
10 \mathrm{~g} \text { margarine } \\
25 \mathrm{~g} \text { jam } \\
30 \mathrm{~g} \text { sausage }\end{array}$ \\
\hline Snack: & $\begin{array}{l}150 \mathrm{~g} \text { banana } \\
25 \mathrm{~g} \text { wholemeal biscuit bar }\end{array}$ \\
\hline Lunch: & $\begin{array}{l}60 \mathrm{~g} \text { roast pork with } 90 \mathrm{~g} \text { mustard sauce } \\
120 \mathrm{~g} \text { carrots } \\
175 \mathrm{~g} \text { rice } \\
300 \mathrm{~g} \text { apple purée }\end{array}$ \\
\hline Snack: & $\begin{array}{l}150 \mathrm{~g} \text { apple } \\
150 \mathrm{~g} \text { fruit yoghurt (minimum } 3.5 \% \text { fat content) }\end{array}$ \\
\hline Dinner: & $\begin{array}{l}100 \mathrm{~g} \text { wheat wholemeal bread } \\
10 \mathrm{~g} \text { margarine } \\
40 \mathrm{~g} \text { sausage } \\
50 \mathrm{~g} \text { tomato }\end{array}$ \\
\hline Snack: & $\begin{array}{l}10 \mathrm{~g} \text { crispbread } \\
5 \mathrm{~g} \text { margarine } \\
17 \mathrm{~g} \text { fresh cheese (minimum } 60 \% \text {, maximum } 85 \% \text { fat content in dry matter) }\end{array}$ \\
\hline Beverages: & $\begin{array}{l}1250 \mathrm{ml} \text { fruit tea } \\
450 \mathrm{ml} \text { coffee } \\
500 \mathrm{ml} \text { apple juice } \\
300 \mathrm{ml} \text { milk (minimum } 3.5 \% \text { fat content) }\end{array}$ \\
\hline
\end{tabular}

Table 3. Menu for diet 2 (vegetarian diet)

\begin{tabular}{|c|c|}
\hline Breakfast: & $\begin{array}{l}50 \mathrm{~g} \text { rolled oats } \\
30 \mathrm{~g} \text { raisins } \\
20 \mathrm{~g} \text { hazelnuts } \\
150 \mathrm{~g} \text { banana }\end{array}$ \\
\hline Snack: & $\begin{array}{l}150 \mathrm{~g} \text { orange } \\
25 \mathrm{~g} \text { wholemeal biscuit bar }\end{array}$ \\
\hline Lunch: & $\begin{array}{l}200 \mathrm{~g} \text { potato purée } \\
240 \mathrm{~g} \text { carrots } \\
55 \mathrm{~g} \text { egg } \\
15 \mathrm{~g} \text { margarine } \\
150 \mathrm{~g} \text { apple }\end{array}$ \\
\hline Snack: & $\begin{array}{l}150 \mathrm{~g} \text { apple } \\
150 \mathrm{~g} \text { banana }\end{array}$ \\
\hline Dinner: & $\begin{array}{l}300 \mathrm{~g} \text { potatoes } \\
125 \mathrm{~g} \text { quark, fresh cheese }(20 \% \text { fat content in dry matter) } \\
100 \mathrm{~g} \text { tomatoes }\end{array}$ \\
\hline Snack: & $\begin{array}{l}50 \mathrm{~g} \text { wheat wholemeal bread } \\
10 \mathrm{~g} \text { margarine } \\
17 \mathrm{~g} \text { fresh cheese (minimum } 60 \% \text {, maximum } 85 \% \text { fat content in dry matter) } \\
150 \mathrm{~g} \text { orange }\end{array}$ \\
\hline Beverages: & $\begin{array}{l}1450 \mathrm{ml} \text { fruit tea } \\
450 \mathrm{ml} \text { coffee } \\
500 \mathrm{ml} \text { apple juice } \\
100 \mathrm{ml} \text { milk (minimum } 3.5 \% \text { fat content) }\end{array}$ \\
\hline
\end{tabular}


Table 4. Composition of the diets*

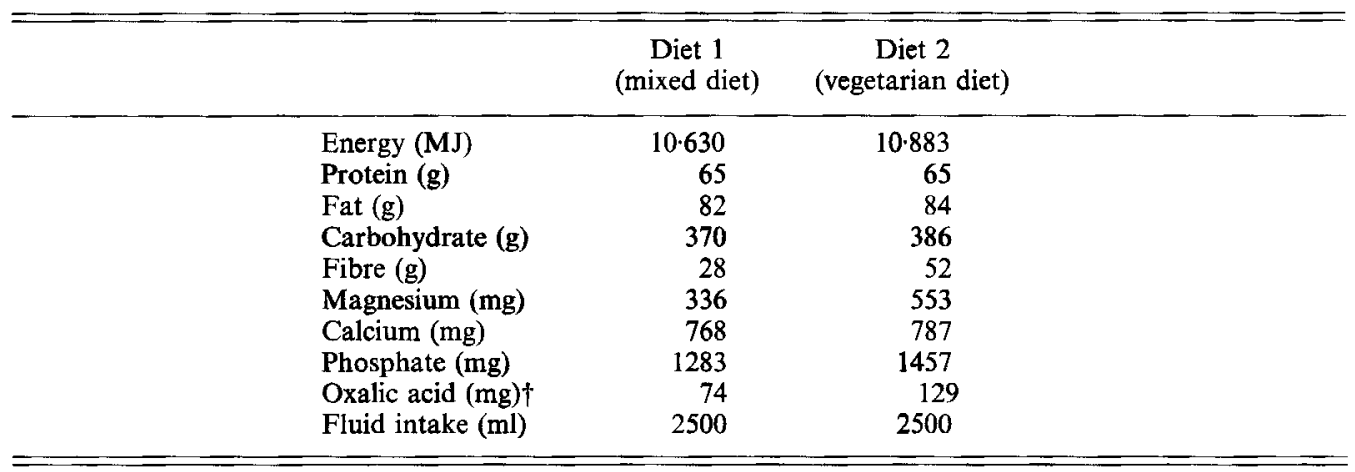

* Estimated by use of the computer program PRODI III plus, based on the Food Composition and Nutrition Tables, 1986/87 of Souci et al. (1986).

$\dagger$ Estimated from the data of Hodgkinson (1977).

Table 5. Dietary fibre and magnesium intakes from a mixed diet and an ovo-lacto-vegetarian diet*

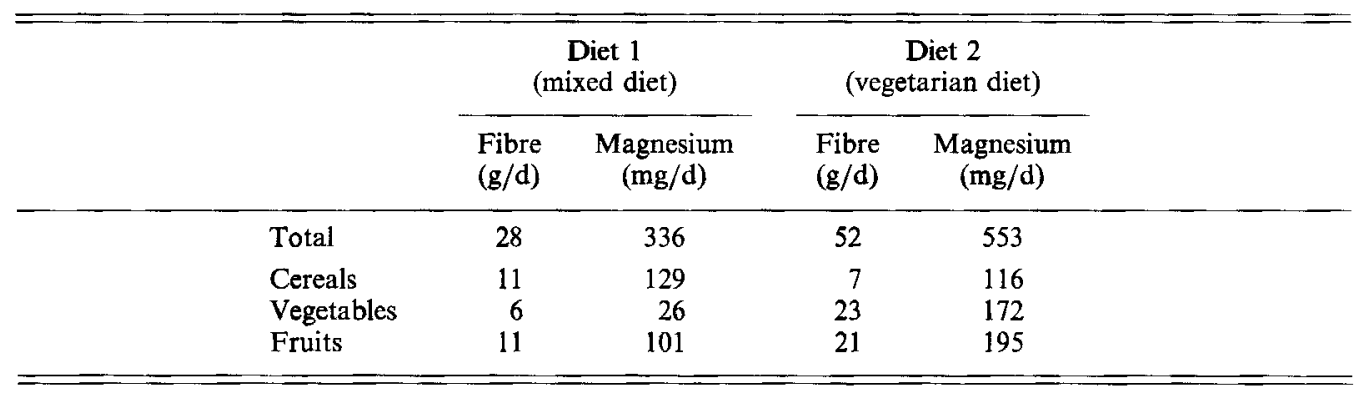

* Estimated by use of the computer program PRODI III plus, based on the Food Composition and Nutrition Tables, 1986/87 of Souci et al. (1986).

$(P<0.05)$ between corresponding days of phases 1 and 2 . As control day the fifth day of phase 1 and as comparative day the fifth day of phase 2 were chosen, because by then conditions of steady state had been reached.

\section{RESULTS}

The results are summarized in Table 6 . Mean $\mathrm{Mg}$ excretion was $5.34 \mathrm{mmol} / \mathrm{d}$ on the normal-Mg-containing diet 1 and increased to $5.69 \mathrm{mmol} / \mathrm{d}$ on average on consumption of the $\mathrm{Mg}$-rich vegetarian diet 2. The difference between the $\mathrm{Mg}$ excretion on the mixed diet 1 (days 1-5) and that on the vegetarian diet 2 (days 6-10) was not statistically significant.

To estimate the approximate excretion rate of $\mathrm{Mg}$ from both diets, the $\mathrm{Mg}$ input and output on the last day of each phase had to be compared (Table 7). The $\mathrm{Mg}$ content of the mixed diet 1 amounted to $13.8 \mathrm{mmol} / \mathrm{d}$, whereas $22.8 \mathrm{mmol} \mathrm{Mg} / \mathrm{d}$ were supplied by diet 2 , corresponding to an increase of $\mathrm{Mg}$ intake of $65 \%$. On the other hand, 5.09 (SEM 0.35) $\mathrm{mmol}$ $\mathrm{Mg}$ were excreted on the control day during the ingestion of diet 1 , compared with 5.40 (SEM 0.52) $\mathrm{mmol}$ on the comparative day during the intake of diet 2, which is an increase 
Table 6. Urinary volume, oxalic acid and mineral excretion by healthy male subjects consuming a mixed diet (diet 1 ) and an ovo-lacto-vegetarian diet (diet 2) $\dagger$

(Mean values with their standard errors for ten subjects)

\begin{tabular}{|c|c|c|c|c|c|c|c|c|c|c|}
\hline \multirow[b]{2}{*}{ Day... } & \multicolumn{5}{|c|}{ Diet 1} & \multicolumn{5}{|c|}{ Diet 2} \\
\hline & 1 & 2 & 3 & 4 & 5 & 6 & 7 & 8 & 9 & 10 \\
\hline $\begin{array}{r}\text { Urinary volume (litres/d) } \\
\text { SEM }\end{array}$ & $\begin{array}{l}2 \cdot 54 \\
0 \cdot 21\end{array}$ & $\begin{array}{l}2 \cdot 40 \\
0 \cdot 13\end{array}$ & $\begin{array}{l}2 \cdot 41 \\
0 \cdot 23\end{array}$ & $\begin{array}{l}2 \cdot 30 \\
0 \cdot 14\end{array}$ & $\begin{array}{l}2 \cdot 30 \\
0 \cdot 12\end{array}$ & $\begin{array}{l}2 \cdot 80 \\
0 \cdot 16\end{array}$ & $\begin{array}{l}2 \cdot 58 \\
0 \cdot 16\end{array}$ & $\begin{array}{l}2 \cdot 36 \\
0 \cdot 16\end{array}$ & $\begin{array}{l}2 \cdot 65 \\
0 \cdot 11\end{array}$ & $\begin{array}{l}2 \cdot 45 \\
0 \cdot 24\end{array}$ \\
\hline $\begin{array}{l}\text { Magnesium (mmol/1) } \\
\text { SEM }\end{array}$ & $\begin{array}{l}2 \cdot 09 \\
0 \cdot 18\end{array}$ & $\begin{array}{l}2 \cdot 33 \\
0 \cdot 17\end{array}$ & $\begin{array}{l}2.41 \\
0.17\end{array}$ & $\begin{array}{l}2 \cdot 47 \\
0 \cdot 16\end{array}$ & $\begin{array}{l}2 \cdot 25 \\
0 \cdot 16\end{array}$ & $\begin{array}{l}2 \cdot 16 \\
0 \cdot 20\end{array}$ & $\begin{array}{l}2 \cdot 25 \\
0 \cdot 13\end{array}$ & $\begin{array}{l}2 \cdot 47 \\
0 \cdot 18\end{array}$ & $\begin{array}{l}2 \cdot 26 \\
0 \cdot 17\end{array}$ & $\begin{array}{l}2 \cdot 31 \\
0 \cdot 24\end{array}$ \\
\hline Magnesium (mmol/d) & $\begin{array}{l}5 \cdot 07 \\
0 \cdot 34\end{array}$ & $\begin{array}{l}5 \cdot 49 \\
0 \cdot 38\end{array}$ & $\begin{array}{l}5 \cdot 54 \\
0 \cdot 36\end{array}$ & $\begin{array}{l}5 \cdot 51 \\
0 \cdot 27\end{array}$ & $\begin{array}{l}5 \cdot 09 \\
0 \cdot 35\end{array}$ & $\begin{array}{l}5 \cdot 84^{*} \\
0 \cdot 36\end{array}$ & $\begin{array}{l}5 \cdot 66 \\
0 \cdot 26\end{array}$ & $\begin{array}{l}5 \cdot 63 \\
0 \cdot 32\end{array}$ & $\begin{array}{l}5 \cdot 91 \\
0 \cdot 39\end{array}$ & $\begin{array}{l}5 \cdot 40 \\
0 \cdot 52\end{array}$ \\
\hline Calcium (mmol/d) & $\begin{array}{l}4 \cdot 26 \\
0 \cdot 49\end{array}$ & $\begin{array}{l}3.93 \\
0.53\end{array}$ & $\begin{array}{l}3.54 \\
0.47\end{array}$ & $\begin{array}{l}3 \cdot 36 \\
0 \cdot 49\end{array}$ & $\begin{array}{l}3.09 \\
0.44\end{array}$ & $\begin{array}{l}2.99^{*} \\
0.40\end{array}$ & $\begin{array}{l}2 \cdot 70^{*} \\
0 \cdot 40\end{array}$ & $\begin{array}{l}2 \cdot 58^{*} \\
0 \cdot 43\end{array}$ & $\begin{array}{l}2 \cdot 84^{*} \\
0.49\end{array}$ & $\begin{array}{l}2 \cdot 46^{*} \\
0.42\end{array}$ \\
\hline Oxalic acid (mmol/d) & $\begin{array}{l}0.290 \\
0.020\end{array}$ & $\begin{array}{l}0.325 \\
0 \cdot 021\end{array}$ & $\begin{array}{l}0.298 \\
0.019\end{array}$ & $\begin{array}{l}0.297 \\
0.016\end{array}$ & $\begin{array}{l}0 \cdot 287 \\
0 \cdot 018\end{array}$ & $\begin{array}{l}0.378^{*} \\
0.030\end{array}$ & $\begin{array}{l}0.407 \\
0.022\end{array}$ & $\begin{array}{l}0.414^{*} \\
0.031\end{array}$ & $\begin{array}{l}0.411^{*} \\
0.028\end{array}$ & $\begin{array}{l}0.376^{*} \\
0.039\end{array}$ \\
\hline
\end{tabular}

* Mean values were significantly different from those of diet 1 on the corresponding day, $P<0.05$.

$\dagger$ For details of diets and procedures, see Tables 2-5 and pp. 784-786.

Table 7. Intake and excretion of magnesium by healthy male subjects consuming a mixed diet (diet $1 ;$ day 5) or an ovo-lacto-vegetarian diet (diet 2 ; day 10)*

(Mean values with their standard errors for ten subjects)

\begin{tabular}{lcccccc}
\hline \hline & \multicolumn{2}{c}{$\begin{array}{c}\text { Diet 1 } \\
\text { (mixed diet) }\end{array}$} & & \multicolumn{2}{c}{$\begin{array}{c}\text { Diet 2 } \\
\text { (vegetarian diet) }\end{array}$} & \\
\cline { 2 - 3 } & Mean & SEM & & Mean & SEM & $\Delta(\%)$ \\
\hline Mg intake (mmol/d) & 13.8 & & & 22.8 & & 65 \\
Mg excretion (mmol/d) & 5.09 & 0.35 & & 5.40 & 0.52 & 6 \\
Mg excretion rate (\%) & 37 & & & 24 & & \\
\hline \hline
\end{tabular}

* For details of diets and procedures, see Tables 2-5 and pp. 784-786.

of only $6 \%$. At a value of $5.09 \mathrm{mmol} \mathrm{Mg}$ on the last day of phase 1 , renal $\mathrm{Mg}$ excretion amounted to $37 \%$ of the intake. Although $\mathbf{M g}$ supply by diet 2 was considerably higher than with diet $1, \mathrm{Mg}$ excretion increased only by $0.31 \mathrm{mmol} / \mathrm{d}$, which corresponds to $24 \%$ of the ingested amount.

Furthermore, urinary $\mathrm{Mg}$ concentrations were similar to a large extent on the ingestion of both diet 1 and diet 2. The additional water intake from fruits and vegetables of the vegetarian diet 2 resulted in an increase in urinary volume from 2.39 litres/d on average on diet 1 to 2.57 litres/d on diet 2 , an average of $180 \mathrm{ml} / \mathrm{d}$, that equalized the relatively low differences in $\mathrm{Mg}$ excretion between the comparable test days with regard to the concentration.

The $24 \mathrm{~h}$ urinary excretion of $\mathrm{Ca}$ was highest on the ingestion of the mixed diet 1 and then decreased on the intake of the vegetarian diet 2 . The differences were statistically significant.

On diet 1, mean oxalic acid excretion amounted to $0.299 \mathrm{mmol} / \mathrm{d}$ and increased significantly by $33 \%$ to $0.397 \mathrm{mmol} / \mathrm{d}$ on average on diet 2 . 


\section{DISCUSSION}

Magnesium is suggested to be an important inhibitor of calcium oxalate stone formation. If its renal excretion and concentration could be sufficiently enhanced, $\mathrm{Mg}$ might increase the solubility of calcium oxalate by complexing oxalate (Desmars \& Tawashi, 1973).

In order to investigate the importance of a $\mathrm{Mg}$-rich diet as an effective metaphylactic measure in calcium oxalate urolithiasis, a vegetarian diet has been tested in relation to a mixed diet in the expectation that the high $\mathrm{Mg}$ content of fruits, cereals and vegetables would increase urinary $\mathrm{Mg}$ excretion and concentration.

In spite of the use of short-term periods, a tendency in $\mathrm{Mg}$ excretion was noted in the course of the present study. The results indicate that increasing the Mg intake by more than half, the excretion rate, i.e. urinary excretion as a percentage of the intake, clearly diminishes. On consumption of diet $1,37 \%$ of the ingested amount was excreted compared with $24 \%$ on diet 2 .

The main factor that influences $\mathrm{Mg}$ excretion in the urine is the amount of $\mathrm{Mg}$ ingested. The urinary excretion of $\mathrm{Mg}$ in an individual in $\mathrm{Mg}$ balance is a close function of dietary intake and intestinal absorption. As $\mathrm{Mg}$ balance is assumed under standardized conditions the availability can be determined from the renal $\mathrm{Mg}$ excretion.

At average dietary $\mathrm{Mg}$ intakes, $\mathrm{Mg}$ absorption has been found to be approximately 35-40\% of the intake (Wacker \& Parisi, 1968; Wilkinson, 1976; Danielson et al. 1979; Elin, 1987). On extremely low or high dietary $\mathrm{Mg}$ intakes an inverse relationship to the absorption rate has been observed. Graham et al. (1960) showed that $76 \%$ of the ingested $\mathrm{Mg}$ was absorbed with a very low dietary intake of $\mathrm{Mg}(0.95 \mathrm{mmol})$, while a high intake $(23.5 \mathrm{mmol})$ resulted in a decrease in the absorption to $24 \%$.

These findings suggest that $\mathrm{Mg}$ absorption at high dietary $\mathrm{Mg}$ levels, as on the vegetarian diet 2 which supplied $22.8 \mathrm{mmol} / \mathrm{d}$, is much lower than on normal intakes. The experimentally determined values of the present study agree with the findings of Jahnen et al. (1991). On a diet containing $16.45 \mathrm{mmol} \mathrm{Mg} / \mathrm{d} 4.34 \mathrm{mmol} \mathrm{Mg} / \mathrm{d}$ were excreted on average, which corresponds to $26 \%$ of the supply. On an intake of $34.96 \mathrm{mmol} \mathrm{Mg} / \mathrm{d}$ (16.45 mg with the diet $+18.51 \mathrm{mg} \mathrm{Mg}$ with effervescent tablets) a mean excretion of $6.1 \mathrm{mmol} \mathrm{Mg} / \mathrm{d}$ resulted, which is $17.4 \%$ of the intake.

A number of nutritional factors have been indicated to influence $\mathrm{Mg}$ absorption and excretion, e.g. the carbohydrate, fat, protein, $\mathrm{Ca}$ and phosphate contents of the diet (Wilkinson, 1976; Seelig, 1981).

Whereas in the present study both diets contained similar amounts of the main nutrients and of $\mathrm{Ca}$, the ingested amount of phosphate with diet $2(1457 \mathrm{mg})$ was greater than with diet $1(1283 \mathrm{mg})$. As a mechanism of action, the ability of phosphate to form a complex with $\mathrm{Mg}$ in the gastrointestinal tract, which makes $\mathrm{Mg}$ unavailable for absorption, is assumed (Wilkinson, 1976; Pak et al. 1985).

Another food component that is suggested to be effective in decreasing $\mathrm{Mg}$ absorption is phytic acid. Phosphate in phytic acid is able to bind $\mathrm{Mg}$, thus interfering with the bioavailability and absorption of this essential mineral (Hartmuth-Hoene, 1985; Franz, 1989). Phytic acid is widely found in whole grains and legumes (Franz, 1989), but with regard to the vegetarian diet 2 the influence of phytic acid on $\mathrm{Mg}$ absorption is of minor interest, since the diets did not differ greatly in the proportion of phytic-acid-rich foods they contained.

Recently, attention has been focused towards a possible role of a high intake of dietary fibre in impaired $\mathrm{Mg}$ absorption. Whether intake of fibre may exert an effect on $\mathrm{Mg}$ absorption from the diet is still debated (Kelsay et al. 1979; McHale et al. 1979; Slavin \& Marlett, 1980), since chemical determinations of $\mathrm{Mg}$ in the food do not indicate the amount 
available for absorption (Frølich, 1986). Fruits and vegetables in diet 1 supplied $39 \%$ of total dietary $\mathrm{Mg}$ and $60 \%$ of total dietary fibre. In diet 2, 66\% of the $\mathrm{Mg}$ and $84 \%$ of the fibre were provided by fruits and vegetables, representing an increase in both dietary $\mathbf{M g}$ and fibre supply from fruits and vegetables by about $25 \%$.

The higher fibre intake from fruits and vegetables with the vegetarian diet 2 than that with the mixed diet 1 might have influenced the $\mathrm{Mg}$ excretion, possibly by decreasing $\mathrm{Mg}$ utilization and absorption. This may correspond to losses of $\mathrm{Mg}$ in the faeces. Further studies on this question should therefore incorporate collection and analysis of faeces. Moreover, longer feeding periods may be necessary if adaptation by the intestine to higher dietary $\mathrm{Mg}$ and fibre levels is to be considered.

On the other hand, $\mathrm{Mg}$ has been suggested to influence the excretion of $\mathrm{Ca}$. Balance studies in man (Heaton \& Parsons, 1961; Briscoe \& Ragan, 1966) have shown that oral administration of $\mathrm{Mg}$ causes a substantial fall in the faecal excretion of $\mathrm{Ca}$, suggesting that the increased urinary excretion of $\mathrm{Ca}$ may result from an increased intestinal absorption of $\mathrm{Ca}$ and not necessarily from competition for reabsorption between $\mathrm{Ca}$ and $\mathrm{Mg}$ in the renal tubule. Raising $\mathrm{Mg}$ intake with diet 2 compared with diet 1 did not increase $\mathrm{Ca}$ excretion. Here, the effect of an excess $\mathrm{Mg}$ supply on $\mathrm{Ca}$ excretion is mitigated by several other factors such as the dietary fibre and oxalic acid contents of the vegetarian diet.

Furthermore, it has been suggested that $\mathrm{Mg}$ decreases the oxalate excretion either by affecting its absorption (Berg et al. 1986), or by regulating the endogenous synthesis as the $\mathrm{Mg}$ ion is a cofactor in the decarboxylation of glyoxylate. However, a reduction in oxalic acid excretion on $\mathrm{Mg}$ administration was only reported by Brundig et al. (1981) and Berg et al. (1986). The majority of investigations have revealed no significant differences in oxalic acid excretion on Mg therapy (Elliot \& Ribeiro, 1971; Gregory et al. 1977; Tiselius et al. 1980; Nordenvall et al. 1985). On the contrary, ingestion of the Mg-rich vegetarian diet 2 resulted in a significant increase in oxalic acid excretion, predominantly caused by the high oxalate content of the plant foods.

The influence of a $\mathrm{Mg}$-rich ovo-lacto-vegetarian diet on urinary $\mathrm{Mg}$ excretion and urinary concentration was not as great as expected. Moreover, on the basis of the high oxalic acid excretion caused by the oxalic acid content of the plant foods, calcium oxalate stone formers with a mild hyperoxaluria, due to intestinal hyperabsorption of oxalate, should be advised to avoid an excess of fruits, vegetables and cereals.

This study was supported by Deutsche Forschungsgemeinschaft He 1132/3-3.

\section{REFERENCES}

Achilles, W. \& Ulshöfer, B. (1985). The effect of magnesium on the crystal growth rate of calcium oxalate in human urine. Magnesium-Bulletin 7, 114-116.

Berg, W., Bothor, C., Pirlich, W. \& Janitzky, V. (1986). Influence of magnesium on the absorption and excretion of calcium and oxalate ions. European Urology 12, 274-282.

Briscoe, A. M. \& Ragan, C. (1966). Effect of magnesium on calcium metabolism in man. American Journal of Clinical Nutrition 19, 296-306.

Brundig, P., Berg, W. \& Schneider, H. J. (1981). The influence of magnesium chloride on blood and urine parameters in calcium oxalate stone patients. European Urology 7, 97-99.

Daniclson, B. G., Johansson, G., Jung, B., Ljunghall, S., Lundqvist, H. \& Malmborg, P. (1979). Gastrointestinal magnesium absorption. Kinetic studies with ${ }^{28} \mathrm{Mg}$ and a simple method for determination of fractional absorption. Mineral and Electrolyte Metabolism 2, 116-123.

Desmars, J. F. \& Tawashi, R. (1973). Dissolution and growth of calcium oxalate monohydrate. I. Effect of magnesium and pH. Biochimica et Biophysica Acta 313, 256-267.

Deutsche Gesellschaft für Ernährung (1986). Empfehlungen für die Nährstoffzufuhr (Recommendations for Nutritional Intake). Frankfurt: Umschau-Verlag.

Elin, R. J. (1987). Assessment of magnesium status. Clinical Chemistry 33, 1965-1970.

Elliot, J. S. \& Ribeiro, M. E. (1971). Magnesium and calcium oxalate solubility. Investigative Urology 8, 386-390. 
Fetner, C. D., Barilla, D. E., Townsend, J. \& Pak, C. Y. C. (1978). Effects of magnesium oxide on the crystallization of calcium salts in urine in patients with recurrent nephrolithiasis. Journal of Urology 120 , 399-401.

Franz, K. B. (1989). Influence of phosphorus on intestinal absorption of calcium and magnesium. In Magnesium in Health and Disease, pp. 71-78 [Y. Itokawa and J. Durlach, editors]. London: John Libbey \& Co. Ltd.

Frolich, W. (1986). Bioavailability of minerals from cereals. In Handbook of Dietary Fiber in Human Nutrition, pp. 173-191 [G. A. Spiller, editor]. Boca Raton, Florida: CRC Press Inc.

Graham, L. A., Caesar, J. J. \& Burgen, A. S. V. (1960). Gastrointestinal absorption and excretion of $\mathrm{Mg}^{28}$ in man. Metabolism: Clinical and Experimental 9, 646-659.

Gregory, J. G., Park, K. Y. \& Schoenberg, H. W. (1977). Oxalate stone disease after intestinal resection. Journal of Urology 117, 631-634.

Hallson, P. C., Rose, G. A. \& Sulaiman, S. (1982). Magnesium reduces calcium oxalate crystal formation in human whole urine. Clinical Science 62, 17-19.

Hartmuth-Hoene, A. E. (1985). Die biologische Verfügbarkeit von Magnesium in Weizenkleie mit unterschiedlichem Phytatgehalt. (The bioavailability of magnesium in wheat bran with different phytate content). Magnesium-Bulletin 7, 29-32.

Heaton, F. W. \& Parsons, F. M. (1961). The metabolic effect of high magnesium intake. Clinical Science 21, $273-284$.

Hodgkinson, A. (1977). Oxalic Acid in Biology and Medicine. New York: Academic Press.

Jahnen, A., Scharrel, O. \& Hesse, A. (1991). The availability of magnesium from various preparations. In Magnesium - a Relevant Ion, pp. 377-382 [B. Lassere and J. Durlach, editors]. London: John Libbey \& Co. Ltd.

Kelsay, J. L., Behall, K. M. \& Prather, E. S. (1979). Effect of fiber from fruits and vegetables on metabolic responses of human subjects. II. Calcium, magnesium, iron, and silicon balances. American Journal of Clinical Nutrition 32, 1876-1880.

Kohri, K., Garside, J. \& Blacklock, N. J. (1988). The role of magnesium in calcium oxalate urolithiasis. British Journal of Urology 61, 107-115.

Li, M. K., Blacklock, N. J. \& Garside, J. (1985). Effects of magnesium on calcium oxalate crystallization. Journal of Urology 133, 123-125.

McHale, M., Kies, C. \& Fox, H. M. (1979). Calcium and magnesium nutritional status of adolescent humans fed cellulose or hemicellulose supplements. Journal of Food Science 44, 1412-1417.

Nordenvall, B., Backman, L., Larsson, L. \& Tiselius, H. G. (1985). Treatment of hyperoxaluria in patients with jejunoileal bypass: effects of calcium, aluminium, magnesium and cholestyramine. In Urolithiasis and Related Clinical Research, pp. 585-588 [P. O. Schwille, L. H. Smith, W. G. Robertson and W. Vahlensieck, editors]. New York: Plenum Press.

Pak, C. Y. C., Nicar, M. J. \& Kreijs, G. J. (1985). Intestinal absorption of calcium, magnesium, phosphate and oxalate: deviation from normal in idiopathic urolithiasis. In Urolithiasis and Related Clinical Research, pp. 127-133 [P. O. Schwille, L. H. Smith, W. G. Robertson and W. Vahlensieck, editors]. New York: Plenum Press.

Sachs, L. (1984). Angewandte Statistik (Applied Statistics). Berlin, Heidelberg, New York: Springer.

Seelig, M. S. (1981). Magnesium requirements in human nutrition. Magnesium-Bulletin 3, 26-47.

Slavin, J. L. \& Marlett, J. A. (1980). Influence of refined cellulose on human bowel function and calcium and magnesium balance. American Journal of Clinical Nutrition 33, 1932-1939.

Souci, S. W., Fachmann, W. \& Kraut, H. (1986). Food Composition and Nutrition Tables 1986/87. Garching: Deutsche Forschungsanstalt für Lebensmittelchemie.

Tiselius, H. G., Ahlstrand, C. \& Larsson, L. (1980). Urine composition in patients with urolithiasis during treatment with magnesium oxide. Urological Research 8, 197-200.

Wacker, W. E. C. \& Parisi, A. F. (1968). Magnesium metabolism. New England Journal of Medicine 278, 658 663.

Wilkinson, R. (1976). Absorption of calcium, phosphorus and magnesium. In Calcium, Phosphate and Magnesium Metabolism, pp. 35-115 [B. E. C. Nordin, editor]. Edinburgh: Churchill Livingstone. 